This item was submitted to Loughborough's Research Repository by the author.

Items in Figshare are protected by copyright, with all rights reserved, unless otherwise indicated.

Policy entrepreneurship and multi-level governance: a comparative study of European cross-border regions

PLEASE CITE THE PUBLISHED VERSION

PUBLISHER

(C) Pion Ltd

LICENCE

CC BY-NC-ND 4.0

REPOSITORY RECORD

Perkmann, Markus. 2019. "Policy Entrepreneurship and Multi-level Governance: A Comparative Study of European Cross-border Regions". figshare. https://hdl.handle.net/2134/2185. 
This item was submitted to Loughborough's Institutional Repository by the author and is made available under the following Creative Commons Licence conditions.

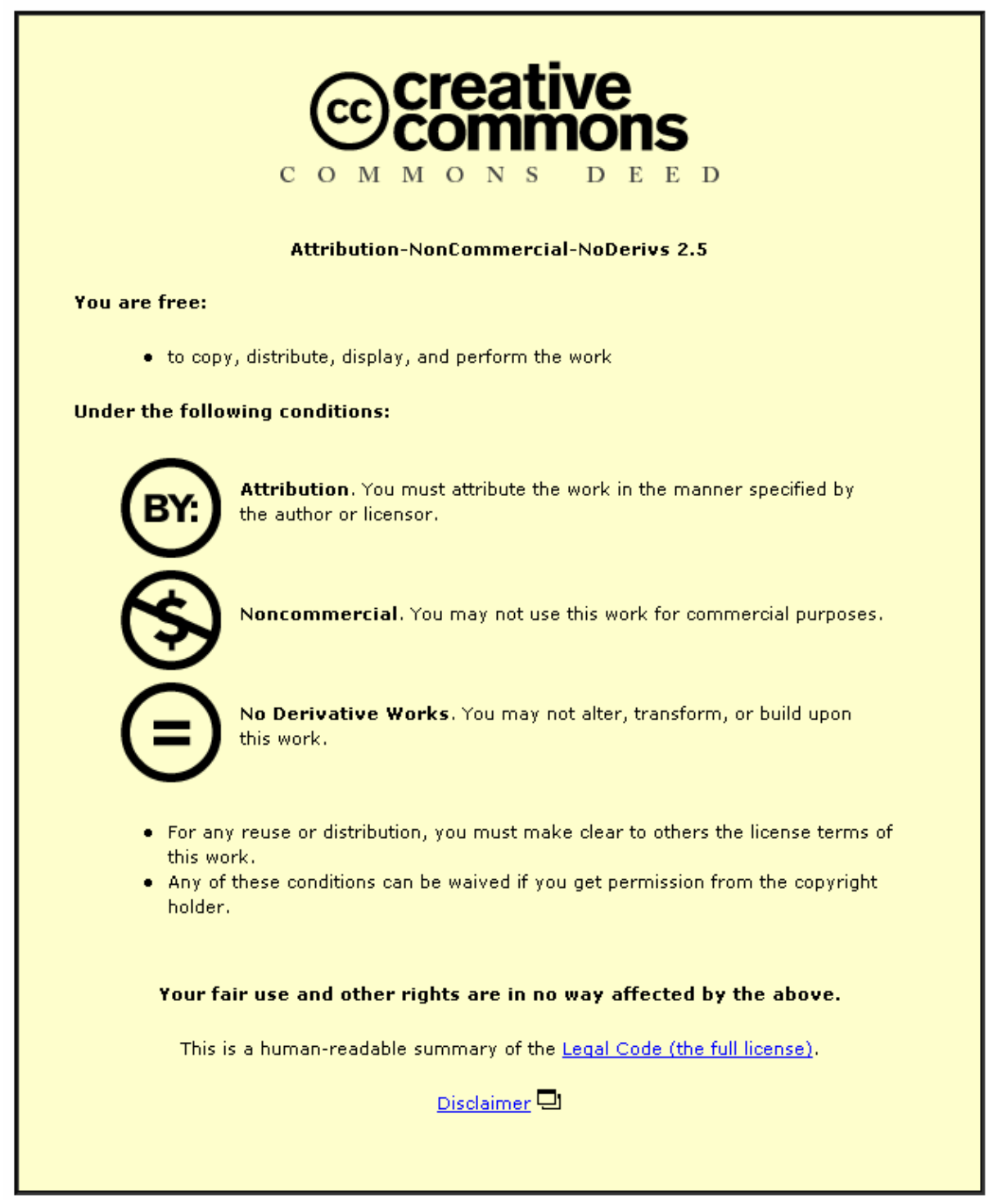

For the full text of this licence, please go to: http://creativecommons.org/licenses/by-nc-nd/2.5/ 


\title{
Policy entrepreneurship and multi-level governance: a comparative study of European cross-border regions
}

This article addresses the recent proliferation of Cross-Border Regions, or Euroregions, in Europe. It argues that EU multi-level governance patterns generate opportunities for entrepreneurial policy organisations to attract policy tasks and resources. This is conceptualised as policy entrepreneurship and applied to a comparative case study analysis of three Euroregions: EUREGIO (Germany - Netherlands), Viadrina (Poland Germany) and Tyrol (Austria - Italy). The analysis focuses on the ability of these initiatives to establish themselves as autonomous organisations. It finds considerable variation across the cases in this respect. Following on from this, the paper shows how different administrative and institutional environments in different EU member states affect the ability of Euroregions to engage in policy entrepreneurship. It concludes that is it premature to perceive Euroregions as new types of regional territorial entities; rather, they are part of the policy innovation scenario enabled by EU multi-level governance.

\author{
Markus Perkmann \\ Wolfson School \\ Loughborough University \\ Loughborough LE11 3TU (UK) \\ +441509227674
}




\section{Introduction}

Virtually all European borders areas are involved in some type of cross-border region (CBR). Today, there are more than seventy such arrangements in Europe, usually operating under names such as 'Euroregions' or 'Working Communities'. Although CBRs have a long tradition in post-war Western Europe (O'Dowd, 2003), the 1990s saw a large increase all over Europe.

Among the various models, 'Euroregions' have certainly received most recent attention in policy practice, mostly because they fit the organisational and spatial requirements of the EU support programme for CBRs. As opposed to the larger, multi-regional Working Communities that often spread over several countries, Euroregions are small-scale groupings of contiguous public authorities across one or more nation-state borders and can be referred to as 'micro-CBRs' (Perkmann, 2003).

Are Euroregions a new type of region, spanning national borders and creating cross-border territories? As such, they would insert themselves into the wider tendencies of 'rescaling' and 'reterritorialisation' theorised by various observers (Blatter, 2001; Jessop, 2002; Brenner, 1999). At the same time however, others have emphasised the patchy track record of European CBRs, both in terms of institution-building as well as their actual impact on local cross-border environments (Beck 1997; Church and Reid 1999; Liberda 1996; Scott 1998; Sidaway 2001). Even the European Commission - the main sponsor of many of these collaboration initiatives - accepts that it has generally been difficult to induce genuine cross-border collaborative projects (O'Dowd, 2003). Against this background, the apparently even proliferation of Euroregions across the EU warrants some further investigation.

This paper pursues two objectives. Firstly, it aims to establish that there is great variation across different cases of Euroregions particularly in relation to the degree to which they have established themselves as independent organisational actors. Secondly, it explores the institutional conditions across different countries that facilitate such an organisational emancipation of Euroregions.

For the first objective, I use the concept of policy entrepreneurship as an 
analytical lens for capturing variation. The concept provides a tool to assess to what degree Euroregions represent actual actors able to shape their environment. It thereby makes it possible to discriminate between Euroregions which have achieved a certain capacity to act and those which are mere ceremonial envelopes or administration vehicles for EU programmes.

The analysis is set against the background of the EU multi-level governance system that provides opportunities for new types of policy actors to appropriate policy competencies and resources in an entrepreneurial fashion. It assumes that for CBRs to have an impact as independently constituted actors, they require an organisational basis, complemented by the capability to mobilise a resource stream to fuel the enactment of cross-border strategies and related interventions.

Although some contributions have addressed differences between Europe and North America (Blatter, 2001; Brunet-Jailly, 2004), a systematic comparison of Euroregions has been largely missing from the literature. A comparative case study approach can be seen as complementary to quantitative work on the proliferation and forms of European CBRs (Perkmann 2003).

To address the second objective, the paper explores the factors behind the uneven development of local cross-border relationships across the European Union. Particular emphasis is placed on the political-administrative context in which Euroregions developed and propositions are developed as to what context conditions are conducive to successful cross-border regions.

The paper is organised as follows: First, I provide an overview on the specificities of European CBRs. Second, I introduce a framework that conceptualises crossborder regions within wider developments in the European polity and builds on the ideas of policy entrepreneurship and resource mobilization. The third section discusses the methods used and provides brief overviews on the single cases: the EUREGIO, the Viadrina and the Tyrol. The case study evidence is then compared across the cases by using operational criteria provided by the policy entrepreneurship framework. The conclusion synthesises the results and identifies the facilitating factors behind successful cases of CBC. 


\section{Cross-border regions, the European experience}

\subsection{Characteristics of European cross-border regions}

European CBRs represent policy-driven rather than market-driven cases of local cross-border integration. This distinction can be made against the background of the main drivers of cross-border integration processes. In this respect, two main integration scenarios can be distinguished:

(a) Market-driven integration: based on the proliferation and/or reactivation of social or economic relationships. Such processes of cross-borderisation can often be found to predominate in case of persisting borders where highly accentuated cross-border differentials stimulate strong cross-border activity, for instance in terms of factor costs such as labour. Examples are provided by 'Greater China' (Sum, 2002) or the US-Mexican border (Scott, 1999); in each of these cases, market-driven integration processes were induced by the declaration of Special Economic Zones.

(b) Policy-driven integration: based on the building of co-operative relationships between public and other bodies that share certain interests, such as coping with environmental interdependencies or creating cross-border economic spaces. These networks often emerge in response to the failures of central state authorities, with local and regional actors exploiting the new opportunity structures created by regionalisation and globalisation. Examples are provided by most European CBRs but also 'compensatory' meso-level networks that emerge as a reaction to the interdependencies or negative externalities created by market-driven cross-border integration, such as on the US-Mexican border (Scott, 1999).

European CBRs can be largely characterized as policy-driven focused on the building of meso-level cross-border policy institutions. This applies in particular to micro-CBRs - or Euroregions in common parlance - which are institutionally the most developed type of CBR in Europe.

In practice, such CBRs are defined by three characteristics (Perkmann, 2003). First, they belong to the realm of public agency, with their protagonists being contiguous sub-national public authorities on local, district or regional levels from 
two or more countries. Many CBRs emerged as a result of the stabilisation of cross-border contacts over time, involving a de-facto institutionalisation of governance structures, decision-making mechanisms and distribution rules. Secondly, CBRs are often based on informal or 'quasi-juridical' arrangements among the participating authorities. This is because subnational authorities are usually not allowed to agree international treaties with foreign authorities. Third, in substantive terms, CBRs are foremost concerned with practical problemsolving in a broad range of fields of everyday administrative life; these tend to be local policy areas with a perceived need for policy co-ordination or the management of cross-border interdependencies. In this respect, nearly all CBRs are concerned with implementing measures funding by the EU programme Interreg (cf. below) which include such diverse fields as SME support, technology and innovation, education and culture, labour market, spatial planning and the environment.

Organisationally, many Euroregions have a council, a presidency, subject-matter oriented working groups and a secretariat. Thus, the term ' $\mathrm{CBR}$ ' refers to both a territorial unit, made up of the aggregate territories of participating authorities, and an organisational entity, usually the secretariat or management unit. In most cases, the participating bodies are local authorities, although sometimes regional or district authorities are involved. Occasionally, other organisations, such as regional development agencies, interest associations and chambers of commerce also participate in the governance of the CBR. The spatial extension of microCBRs will usually range between 50 and $100 \mathrm{~km}$ in width; and they tend to be inhabited by a few million inhabitants.

\subsection{European CBC: history and supranational policy context}

The first formal CBR, the EUREGIO, was established in 1958 on the DutchGerman border, shortly followed by a number of initiatives along the Rhine basin, notably the Regio Basiliensis around Basel (Speiser 1993). Today municipalities, districts and regional authorities in more than seventy locales co-operate with their counterparts via a variety of organisational arrangements.

Crucially, this process was facilitated by supranational institutions, such as the 
Council of Europe ${ }^{1}$ and the European Union. Resultant partly from strategies of transnational collective representation pursued by border authorities, they helped create the conditions under which border authorities could collaborate in a situation characterised by legal uncertainty and 'soft' institutions. The classical form of the Euroregion is the 'twin association': on each side of the border, municipalities and districts form an association according to a legal form suitable within their own national legal system. In a second step, the associations then join each other on the basis of a cross-border agreement - traditionally according to private law - to establish the CBR.

In 1980, an international treaty, known as Madrid Convention was agreed to provide a first step towards CBR structures based on public law. Many Euroregions however do not (yet) make use of this legal-institutional opportunity, preferring to collaborate on the basis of alternative agreements. The Madrid Convention therefore failed to live up to the hopes of the proponents of CBRs which were to provide a strong alternative to centrally controlled 'border commissions' for governing trans-border interdependencies.

By contrast, a supranational policy of great impact was created when the European Commission launched the Interreg I programme, designed to financially support CBRs, in 1990. This was followed by Interreg II (1994-99) and Interreg III (2000-06); the latter was allocated a budget of $€ 4.875 \mathrm{~b}$ (1999 prices), corresponding to approximately $2.3 \%$ of the total regional policy budget of the EU.

Local and regional authorities and other organisations located on external ${ }^{2}$ and internal land borders, as well as some maritime areas, are eligible to apply for Interreg support to pursue cross-border projects. As the European Commission's objective is to develop cross-border social and economic centres through common development strategies, eligible projects are required to demonstrate a structural economic benefit to the border area. The allocation of funds is governed by

\footnotetext{
${ }^{1}$ The Council of Europe $(\mathrm{CoE})$ is a intergovernmental organisation headquartered in Strassbourg founded in 1949.

${ }^{2}$ Borders with non-EU members.
} 
Steering Committees controlled by higher-level authorities (central governments and/or regional authorities) as they are responsible for the lawful implementation of policies towards the European Commission.

\section{Euroregions and policy entrepreneurship}

Interreg is by far the most important source of funding for most micro-CBRs, raising the question whether these initiatives exist only because this type of resource is available. In that case, they would qualify as hardly more than 'grant coalitions' (Cochrane, Peck and Tickell 1996) that disintegrate once the funding stream runs out. The evidence suggests this may be the case for some, but certainly not all CBRs in Europe. On the other hand, observers have pointed out that a certain degree of 'entrepreneurial' behaviour can actually indicate an effective empowerment of the regions against their central-state authorities within the context of EU integration (Smyrl 1997); in this sense, their ability to mobilise funding could be interpreted as success.

In this section, I suggest a way of going beyond the binary choice between 'instrumental' and 'genuine' collaboration by offering a framework that can discriminate between different cases. This builds on ideas derived from the new institutionalism in political and organisational analysis (March and Olsen 1984) that conceive policy developments in the context of institutional constraints and opportunities. Specifically, the concept of policy entrepreneurship is used to understand the emergence of policy organisations in contexts of relative openness that characterise the operation of European cross-border regions.

\subsection{Euroregions, multi-level governance and state re-structuring}

Empirically speaking, the distinction between instrumental and genuine cooperation motives is difficult to operationalise. It appears more appropriate to focus on outcomes rather than on the more intangible imputed motives for establishing CBRs. Among various possible outcome criteria, this paper makes a conscious choice to focus on organisation-building as a main indicator and outcome of successful co-operation. Euroregions are evaluated as to whether they succeeded in establishing themselves as functioning organisations with some 
degree of autonomy vis-à-vis the participating member authorities on both sides of the border. This criterion allows us to distinguish between co-operation arrangements based on relatively independent organisations and 'committee cooperation' in which decision-making is limited to distributing EU funds as opposed to producing specific and enduring cross-border effects (Beck, 1997).

It should be noted that the focus on organisation-building is one step removed from assessing whether they are effective in furthering economic or social crossborder integration. This choice is based on the assumption that functioning crossborder organisations are more likely than ad-hoc committees to induce crossborder integration as this becomes their organisational mission and basis of survival. The choice is also reinforced by the lack of comparative data on local cross-border integration.

More importantly, an organisational view of Euroregions resonates with a number of themes in the broader literature on European integration and the trends affecting the nation state. On the first theme, the recent literature sheds light on the multi-level governance structures emerging particularly within EU regional policy (Hooghe, 1996; Benz and Eberlein, 1999). This literature is primarily concerned with the impact of Cohesion Policy on territorial organisation in the EU Member States, with an explicit focus on the involvement of regional authorities in decision-making at various stages of the policy process.

Given the interdependence of national and sub-national actors, the European polity can be seen as an interconnected system of non-nested political arenas in which the boundaries between domestic and international politics are increasingly blurred (Marks, 1996). Although the formal sovereignty of the Member States is retained, it is claimed that the unilateral control of states over their territories de facto continues to erode (Conzelmann 1998: 5).

Within this scenario, Hooghe and Marks (2003) argue that a new type of territory has come to complement the traditional type of non-intersecting and nested territory. Such 'type II governance' involves task-specific jurisdictions, intersecting membership and flexibly designed competencies and intervention mechanisms (ibid.). It is easy to see why Euroregions can be seen in this way as an example for such type II structures. They focus on cross-border policy co- 
ordination as their specialist task, they involve members drawn from various different jurisdictions and are flexibly designed to respond to their policy mandate. It follows that organisation-building will be an essential part of the emergence of such type II governance structures.

The focus on organisation-building is reinforced by the specific characteristics of the European policy space. The EU is an atypical policy maker in that it has no implementation agency. It relies on the member states and their subordinate authorities to execute policy. Despite its weak formal powers, however, the EU has a remarkable impact because the procedural requirements laid out in the regulations give the Commission a considerable say over the substantive content of policies. The Cohesion Policy regulations provide various incentives for agency co-operation and co-ordination and hence the creation of policy networks (Heinelt and Smith, 1996). For instance, in many programmes the Commission requires subnational actors to be involved in policy implementation. The 'partnership principle' functions as an effective intervention instrument that allows the Commission to exert influence at all stages of the policy process, i.e. initiation, policy design, implementation and monitoring and evaluation (Tömmel, 1994). The requirement of unanimity ensures that decision-making in the implementation networks relies on consensus-driven bargaining which provides a favourable context for effectiveness-oriented administrative action (Heinelt 1996: 298) as opposed to 'horse-trading' over (re)distributive issues. It is in this networked, multi-level policy space, that policy opportunities arise for specialist, type II governance actors who support the European Commission in implementing policies.

This trend towards type II governance can be read against the context of broader tendencies affecting statehood as outlined by Jessop (2004). On one hand, the 'denationalisation' of statehood involves the shifting of state powers upwards to supranational bodies and down to regional or local states, or even networks of regional or local states. On the other, the retreat of the state implies a shift from 'government to governance' towards self-organising networks of public agency. This "weakening of territorial "power containers" [...] relative to non-territorial forms of political power that are formally independent of state borders' (ibid.) 
refers precisely to the formation of type II governance units. Jessop (2002) details some implications of these processes for the rescaling of territories. In any case it can be assumed that such tendencies indicate the requirement that non-central state agencies build organisational capacity to pursue public and semi-public governance functions. The next section develops a more detailed framework for analysing such organisation-building processes.

\subsection{A framework for comparing Euroregions}

The preceding arguments describe a context that provides an opportunity space for actors capable of assuming policy tasks and attracting resources to execute them. This will almost certainly involve the creation and development of relatively durable and autonomous organisations. In this section, I suggest that the concept of policy entrepreneurship can be used to capture this process. Two bodies of literature are used: work on policy entrepreneurship, and work on resource mobilisation within the context of organisations and social movements.

Within the literature on policy innovation (Mintrom, 1997), policy entrepreneurs are characterised as actors who position themselves as protagonists within specific policy areas by taking advantage of windows of opportunity opened up by conjunctures within their policy environment. Reflecting the 'garbage can model' of organisational choice (Cohen et al 1972), they are in constant search for possible problems for which they can offer a solution (Kingdon 1984; Majone and Tame 1996; Mintrom and Vergari 1996). They do this not necessarily for financial profit but to increase the influence of their organisation or organisational unit which is often correlated to their resource basis.

Recent research on EU policy formation has applied the concept of policy entrepreneurship to the European Commission (Laffan, 1997; Moravcsik, 1999). The Commission is described as a policy agent capable of entrepreneurially exploiting the resources at its disposal in order to generate new policies that are acceptable to various coalitions of member states.

By way of analogy the concept can be applied, with some modifications, to Euroregions. Brouard (1996), for instance, analyses the construction of the Atlantic Arc - a Working Community at the Western fringes of the European 
Union from the UK to Portugal - as a 'political enterprise'. Although not using the notion of policy entrepreneurship, Carmin et al. (2003) show that the emergence of the White Carpathian Euroregion was shaped by environmentally oriented NGOs seizing an opportunity structure which in turn had been created by changes within their national political systems and the availability of European Union support.

For current purposes, I propose to amend these notions of political entrepreneurship in two respects. Firstly, while the notion is often applied to theorise individual agency, i.e. the strategies of entrepreneurial individuals (Kingdon, 1984), I apply the notion to activities and strategies of Euroregions as organisations. In recent work, political scientists have suggested that it is not always possible to trace policy innovation back to individuals but that it needs to be attributed to collectives (Roberts and King, 1996).

Secondly, and following from the last point, strategies to exploit windows of opportunities will be accompanied by a process of organisation-building. As with any other organisation, once a Euroregion is established as such, it will operate to secure organisational survival (McCarthy and Zald, 1977). This will occur within the constraints and opportunities afforded by the organisation's ability to mobilise resource and the specialist competencies it will be able to build up over time. Though mostly applied to social movements, resource mobilisation theory can hence be used to inform an operational framework to assess the success of Euroregions. In particular, it refers to the ability of these organisations to create and maintain a support base on a local level; in most cases, this will involve maintaining networks of local authorities as paying members.

In light of the above considerations, why would Euroregions qualify as policy entrepreneurs? First, unlike most public-sector organisations, Euroregions do not exist on the basis of constitutional or public-law enactments. Their organisational set-up and operating procedures are policy innovations that were developed over time within a context of legal uncertainty and novelty. Second, their resource base is not guaranteed by statutory income streams but is secured only in the short-term and often derived from multiple resources. Third, their areas of responsibility are not defined a priori but were developed over time during a complex search 
process guided by the overall theme, or organisational mission, of CBRs.

It can be argued that under these fluid circumstances successful Euroregions can develop only through active policy entrepreneurship, capable of exploiting windows of opportunity, and resulting in a growing organisational base. For empirical analysis, the concept can be operationalized according to the following criteria:

1. Organisational development: To acquire a relative degree of strategic and operational autonomy vis-à-vis 'ordinary' border authorities, successful Euroregions need to develop as independent organisations with a clear specialisation in CBR matters.

2. Diversification of resource base: Euroregions that depend on Interreg funding risk being reduced to mere implementation agencies for this specific type of EU regional policy. Successful Euroregions can be expected to have more diversified and stable income streams, for instance via membership fees from participating authorities or the appropriation of other policy activities relevant for the border space. However, assuming that the availability of EU funding provides selective incentives (Olson, 1965) for municipalities to shoulder the cost of participation in return for Interreg project funding - which could be indicative for purely 'instrumental' participation - it can be postulated that successful Euroregions will attempt to broaden their resource base to encompass other, more diversified sources.

3. Appropriation of Cross-border co-operation (CBC) activities: Successful Euroregions establish themselves as important players within the overall context of cross-border strategies in a given border area. Such strategies may be pursued by other public or semi-public authorities, commercial entities or civil society organisations. Successful CBR organisations can be expected to appropriate or influence such $\mathrm{CBC}$ strategising in their area and seek to be recognised as legitimate and competent by other players.

In the following section, these criteria are applied to the case studies to capture the variance of CBR initiatives. 


\section{Comments on methods and cases}

A comparative case study approach is used to substantiate the claims advanced above (Eisenhardt, 1989). For each case, qualitative evidence was collected, providing the depth of analysis to allow a detailed understanding of the logic of each case. At the same time, the comparative dimension enabled a schematic differentiation of the features that were at the centre of the present investigation.

Theoretical sampling was applied for selecting the cases. This means cases were selected on the basis of expected differences that would allow the highlighting of theoretical issues. The cases include the EUREGIO, a Dutch-German CBR and one of the oldest in Europe; the 'Pro Europa Viadrina' (forthwith: Viadrina), a German-Polish CBR that until recently reached across the external border of the EU; the 'Europaregion Tyrol' (forthwith: Tyrol Euroregion) between Austria and Italy.

Building on the author's knowledge of European CBRs from previous research, these cases were selected because they promised to vary considerably in relation to the construct of policy entrepreneurship. The cases also differ with respect to:

(a) Type of participating authorities: local authorities (EUREGIO, Viadrina), regional authorities (Tyrol);

(b) Territorial organisation of involved countries: federalist and high municipal autonomy (EUREGIO), federalist/centralist and low municipal autonomy (Tyrol), with an intermediate position for the Viadrina.

There are two source types for the evidence: semi-structured interviews and policy documentation. A total of 35 interviews were held between 1997 and 2000 with individuals involved in the EUREGIO, Viadrina and Tyrol Euroregions. The questions covered the history of cross-border collaboration, organisational structures and processes, network relationships with both local and supra-local authorities. Informants were also asked about interest configurations, visions and strategies, achievements and challenges experienced within the Euroregions. Interviewees were conducted with officials in the cross-border organisations and civil servants at member municipalities, municipal associations, districts, provinces and states working with the cross-border organisations in the Netherlands, Germany, Poland, Austria and Italy. In addition, eight interviews 
were conducted with individuals at the European Commission and other Brusselsbased bodies.

Interviews lasted 1.5 hours on average and were taped and transcribed. References to interviews are coded according to the format ' $\mathrm{iE} 1$ ', ' $\mathrm{iV2}$ ', etc; a list is provided in the annex. The capital letters in the code indicate the cases ('E' for EUREGIO, ' $\mathrm{V}$ ' for Viadrina, ' $\mathrm{T}$ ' for Tyrol, ' $\mathrm{B}$ ' for Brussels). Interviews evidence was complemented with documentary materials: policy and communication materials produced by Euroregions, member authorities, the European Commission and other organisations. Before discussing the evidence in relation to the framework developed above, the cases are briefly described.

Table 1 about here

\subsection{The EUREGIO}

The EUREGIO is one of four Dutch-German CBRs. It has a population of approx. $3 \mathrm{~m}$, consisting of Dutch and German citizens on a balanced basis and approx. 140 municipal members; the largest urban centres are Enschede (NL) and Münster and Osnabrück on the German side.

The EUREGIO dates back to 1958 when municipal associations on both sides of the Dutch-German border decided to engage in collective action to alleviate the relative marginalisation of the local border economies. In 1966, a 'Work Group' was founded to operate as the informal board of the cross-border region. At the same time, a secretariat funded via membership fees was established. At the time, this was distributed across two locations, one on each side of the border. In the mid-seventies, the Work Group was given a formal statute, and an action programme was developed. This formalisation process ended with the establishment of the Council in 1978, the first cross-border regional parliamentary assembly in Europe, consisting of the political delegates of the member authorities.

The EUREGIO pioneered the idea of regional cross-border development strategies, for instance through the 'regional cross-border action programme', 
presented in 1987, which outlined the general strategy for a twenty year period. This action programme constituted the main input for a first Operational Programme under EU Cohesion Policy for the period 1989-1992, funded as a pilot project. When the European Commission launched Interreg I in 1990, the EUREGIO reacted with the speedy elaboration of a second Operational Programme and has since been instrumental in deploying Interreg policy measures in this area.

\subsection{The Viadrina}

The 'Euroregion Pro Europa Viadrina' is one of eight Euroregions which span the borders between Germany and Poland and/or the Czech Republic. It covers the eastern part of the East German State (Land) Brandenburg around the city of Frankfurt/Oder and parts of the Lubuskie and Zachodnio-Pomorskie voivodships (districts) in western Poland and has a population of approx. $1 \mathrm{~m}$.

This cross-border body involves local authorities as well as functional and representational bodies, such as the Chamber of Industry and Commerce and the World Trade Centre Frankfurt (Oder). Similar to the EUREGIO, its bodies include the Council, the Presidency, a secretariat and sector-specific working groups.

The foundation of the Viadrina in 1993 followed the breakdown of the Socialist bloc and German re-unification. Socio-economically, its environment is characterised by strong border differences between the East German and Polish economies generated by radical structural and institutional changes on the German side in the 1990s. Until very recently - i.e. Poland's EU accession - the Viadrina cut through the external EU-border as the German parts were EU territory while the Polish areas were not. Hence only German border areas were eligible for EU Interreg support while the Polish part depended on centrally administered funding from the Polish government.

There were two key motives for establishing the Euroregion. The initial desire to establish neighbourly relationships originated in civil society circles on the German side. A foundation, the 'Frankfurt Bridge' was established whose objective was to contribute to German-Polish 'reconciliation' after the re-opening 
of the border. Almost simultaneously the local authorities, particularly on the German side, were made aware of the prospective availability of EU Interreg funding for $\mathrm{CBC}$. This was also a strong driver for a local co-operation initiative. The process was supported by the Land Brandenburg which under German legislation is responsible for the implementation of EU regional policy programmes and hence had a strong interest in establishing administrative structures suitable for deploying Interreg funding in its border areas. Ultimately, this meant that the organisational form to be chosen for establishing a CBR was going to be a 'Euroregion' - adopting the successful model of the EUREGIO and other mature CBRs - and not a foundation as originally proposed by the civil society actors.

\subsection{The Euroregion Tyrol}

The Tyrol Euroregion has a population of approx. $1.5 \mathrm{~m}$ and involves the provinces of Trentino and South Tyrol (Italy) and the Land Tirol (Austria) with Trento, Bolzano and Innsbruck as the main centres. Here, the motivation for creating the Euroregion ${ }^{3}$ differs entirely from the other two cases. It is an example of a CBR embedded in an ethnic minority context (Luverà 1996). The Germanspeaking southern part of the previous Tyrol County was ceded to Italy after World War I while the Northern part remained with the newly constituted Austrian Republic. It is no surprise that the building of a CBR in this case invoked the common cultural and ethnic heritage of the German-speaking populations in both countries as a common overarching territorial identity, a component largely missing from the other cases.

Politically, the post-war history of South Tyrol is characterised by the struggle for 'self-determination' pursued by the main German-speaking forces. This struggle was successful insofar as an 'autonomous' constitutional status was obtained in 1991 after decade-long negotiations with the Italian central government.

Although cross-border co-ordination and collaboration had been pursued for most of the post-war period, the establishment of a Euroregion as a formal platform was

\footnotetext{
${ }^{3}$ Officially: 'European Region of Tyrol - South Tyrol - Trentino'.
} 
initiated only in the 1990s. As opposed to the EUREGIO and Viadrina, the Tyrol Euroregion does not involve any municipalities or other lower-tier authorities. While in the two former cases the establishment of CBRs resulted from a process of bottom-up regional mobilisation involving a large number of authorities, the Tyrol Euroregion is based on an agreement between a small number of established regional authorities.

\section{Discussion: Comparing Euroregions}

So far I have pursued the argument that the concept of policy entrepreneurship provides a suitable tool for understanding the nature of Euroregions and capturing their variation. In this section, the framework is confronted with the available case evidence. It should be noted that through the isomorphic influence of the Interreg programme, the substantial range of cross-border policies across the different cases is similar. Reflecting a trend affecting EU Cohesion Policy as a whole, activities such as technology and innovation support for commercial firms, universities and research organisations have become more important in financial volume at the expense of the more traditional cross-border policies in the transport, social and cultural fields (iE13). This can be verified by comparing the final reports of Interreg I and II and the intermediate reports for Interreg III published by each initiative. The cases differ however in relation to the extent to which activities are locally controlled by dedicated Euroregion organisations. This is the subject of the comparison in the remainder of this section.

\subsection{Organisation development}

The first element of policy entrepreneurship refers to the degree to which Euroregions have established an organisational basis. Apart from the mere organisational size, this concerns, on one hand the relative autonomy they have achieved within the local and vertical networks of public authorities concerned with cross-border policies and on the other, whether or not they have widened their range of activities by taking on related tasks and competencies within their context.

Among the three cases, the EUREGIO secretariat developed the most advanced 
organisational capability with approx. thirty employees. Although it acted on behalf of more than 140 local authorities, the EUREGIO was not a public authority, at least not as a cross-border unit. This means, inter alia, that the secretariat had no formal competencies nor any guaranteed income streams. Thus the range of tasks assumed by the EUREGIO, and in particular its secretariat, was relatively undefined. This enabled the secretariat to act in an entrepreneurial fashion as long as it had the backing of the member authorities and this relative discretion in defining and expanding its tasks was widely used.

Informants from involved local and central-state authorities acknowledged that the secretariat exerted considerable informal influence on EU programme implementation based on its expertise and local connectedness. On one hand, it acted as a project animator, it ensured that all available funds were allocated and turning initial ideas into project applications ready for submission to the Steering Committee (iE6). A senior NRW official observed: ‘... you can't pull projects like a rabbit out of a hat', implying that the higher-level authorities relied on the EUREGIO in this respect (iE11). On the other hand, it made itself indispensable as a network broker. For genuine cross-border projects, project applicants needed partners on the other side of the border and these relevant contacts were usually established by the secretariat (iE7).

The EUREGIO also managed secretariats for related associations, such as the Interreg Steering and Monitoring Committees, a Dutch-German cultural commission, a socio-economic advisory council, a forum of Belgian-DutchGerman Euroregions and the Association of European Border Regions (AEBR). The development of the Viadrina as an organisation, by contrast, was more limited. Although the Viadrina's headquarters was formally in Poland, the secretariat had separate German and Polish sections of which the larger was in Frankfurt/Oder with approx. eight staff. In terms of its role, the secretariat's activities were essentially confined to administering the deployment of Interreg funds. Compared to the EUREGIO, the Viadrina secretariat had less impact on decision-making relating to the funding of cross-border projects. This was partly to do with the fact that for most of its history Interreg funding was only available to the German side. 
EU support from another programme (Phare) was available for the Polish Areas but the administrative separation proved a barrier to effective cross-border projects and decision-making mechanisms were complex and unwieldy (Grix and Knowles, 2003). Consequently, most projects were merely border projects rather than cross-border activities. The Brandenburg Land administration therefore had the opportunity to operate more hierarchically with regard to of the Euroregion's overall direction, effectively limiting its strategic and operational autonomy: '...the Land [Brandenburg] has a massive say in the selection of projects although its financial contribution is only marginal' (iV5). According to a senior Land official, the Land was generous in offering the Euroregion a seat on the Steering Committee but this meant that 'effectively we created ourselves an unnecessary problem as relationships are difficult...' (iV6).

Such statements are in stark contrast to the EUREGIO where substantial project decisions were made within the EUREGIO organisation and then procedurally approved by the Interreg Steering Committee. A senior civil servant in the Land administration remarked: 'We [the Land] do nothing that is not backed in the EUREGIO bodies; we even do things that do not fit our own priorities. But because it concerns cross-border co-operation we decide to do them' (iE4, similarly E11). This is reinforced by a Dutch government ministry official who stated that 'the central state has less control over the implementation of Interreg because of its cross-border character and the strong status of the EUREGIO' (iE3).

In the Tyrol case a different situation prevailed. In an early attempt in the 1990s, the three participating regional authorities sought to institute the Euroregion as a formal authority recognised by public law in both countries (Toniatti 1997: 32). However, facing local and national opposition fuelled by nationalist, legal and sovereignty-related concerns, the project was abandoned and replaced by a collaboration agreement that remained short of establishing a common secretariat. In this situation, the Euroregion remained a largely symbolic envelope rather than an operational organisation with a coherent strategy. The small secretariat established in the Italian city of Bolzano in the early 2000s acted mainly as a public relations outlet rather than an active driver of cross-border activities. The 
Euroregion Tyrol also lacked the representational and decision-making bodies seen in the other cases. Decisions on cross-border projects were taken at yearly conferences that brought together representatives from the three member authorities, strongly influenced by their executive branches (iT6).

Of the cases considered, the EUREGIO has the most developed organisational capacity This is reflected in its number of employees and the discretion in crossborder matters it is awarded by higher-level authorities. The opposite scenario is represented by the Tyrol Euroregion where organisational capacity is only embryonically developed and decisions are therefore made by committees while the Viadrina occupies an intermediate position.

\subsection{Diversification of resource base}

The second criterion refers to the degree to which Euregional organisations have diversified their resource base away from exclusive reliance on Interreg.

The EUREGIO's standing was reflected in its ability to generate a stable resource flow to maintain its operations. It had considerable income from sources not related to Interreg, notably from a membership fee charged to the member authorities, EUR .29 per inhabitant at the time of writing. ${ }^{4}$ The secretariat proved rather successful in raising project-related funding long before Interreg was launched. In most cases, local funds were complemented by contributions from NRW and the European Commission. For instance, a cultural commission ('Mozer Commission') was funded separately from various regional and national sources in both countries. More recently, the secretariat bid successfully for pilotprojects from the European Commission. Among others, the EUREGIO managed a 'EURES-T' unit concerned with labour market issues, a consumer advice centre and a 'Euro-Info-Center' for SMEs. As a result, the secretariat operated a range of activities that strengthen its profile as cross-border regional advice and citizen's service centre.

The Viadrina also charged a membership fee to member authorities but its resource stream was more narrowly dependent on proceeds from Interreg

\footnotetext{
${ }^{4}$ www.euregio.de, accessed 12/04/2006.
} 
'technical assistance'. These are the funds allocated to local agencies to cover the costs of the administration of Interreg, as opposed to those available to project applicants for cross-border projects which constitute the majority of EU funding. The EUREGIO managed to obtain a larger share of those latter funds available compared to the Viadrina by being a project applicant and owner itself. This further increased the EUREGIO's resource position and promoted its organisation-building efforts.

Given the low profile of the Tyrol Euroregion as an organisation, the question of resource base diversification does not apply. It is significant, however, that this Euroregion is not involved in the implementation of Interreg and is hence not funded by Interreg technical assistance. One reason for this is that the area designated for Interreg support by the European Commission does not exactly correspond to the territories of the co-operating regional authorities. In addition, the participating authorities do not depend on Interreg for running a Euroregion as, compared to the municipalities in the EUREGIO and Viadrina cases, these are regional authorities for whom the material contribution of Interreg funding is small.

Among the three cases, the EUREGIO secretariat has gone furthest in diversifying its resource base although Interreg still constitutes by far the largest share of income. Even at this level, however, the EUREGIO's efforts differentiate it from the Viadrina which relies almost exclusively on Interreg technical assistance. Due to its embryonic status, the criterion is not applicable at all to the Tyrol Euroregion.

\subsection{Appropriation of cross-border activities}

The final criterion suggested by the policy entrepreneurship framework refers to the degree to which Euroregional organisations appropriate cross-border policy activities within their area. This section therefore assesses the extent to which Euroregions were involved as protagonists or at least participants in other policy activities aimed at promoting cross-border integration in their areas.

The EUREGIO appeared to have established itself as a highly regarded regional development agency in the Dutch-German border area: 'In our [geographic] area, 
cross-border co-operation is automatically associated with the EUREGIO' (iE6). Beyond being an implementation unit acting on behalf of the European Commission and the involved member states, the EUREGIO had become the undisputed reference point for all 'cross-border issues' in the local environment and was recognised as such by the local authorities on both sides of the border: '[The EUREGIO] has become a natural part of the day-to-day administrative life' (iE9, similar iE12).

This status as regional development agency for a cross-border space was reflected in the ambitions of its functionaries. The objective was the transformation of the cross-border area into a 'central location in North-West Europe' (Gabbe, 1985: 95). Policy frameworks inspired by the idea of a homogenous region have existed since the early stages of the EUREGIO. The vision of a 'functional unit in all spheres of life' between the Dutch Randstad and the German Ruhr originated in the late sixties, if not earlier (CoE, 1972: 111). The development of such visions can be seen as important in constituting a strategic envelope for the organisationbuilding strategies of the EUREGIO.

The EUREGIO's appropriation of Interreg implementation before the programme was launched illustrates its entrepreneurial capability to exploit policy opportunities. In the $1980 \mathrm{~s}$, member municipalities agreed to increase their financial contribution in the expectation that this would help secure a substantial local impact on the allocation of future European funding (iE5). The EUREGIO hence grasped a strategic opportunity when it was still undecided whether a largescale CBC support programme would be launched by the European Commission. The result was that when Interreg was finally launched, with fifteen staff members the EUREGIO secretariat was the natural candidate for the management of the programme in its area: ' ... the EUREGIO was already there, it was obvious that they were going to do the programme management.' (iE1).

In comparison, the Viadrina's remit was limited to administering Interreg funds and it failed to be a relevant player in a number of other policy initiatives targeted at the German-Polish border space. Various commentators have noted that the Euroregion failed to deliver on the inflated expectations it nurtured in the initial period (Grix and Knowles, 2003; Scott, 1998). 
For instance, the Euroregion was not involved in talks between the operators of 'Technology Park', a high-tech industrial estate operator in Frankfurt (Oder), and the Special Economic Zone set up by the Polish government in Kostrzyn-Słubice (iV11, iV13) in the late 1990s. The operators were considering jointly developing 'cross-border packages' for investors. The Euroregion was also absent from drawing up plans for cross-border industrial estates, i.e. bi-national areas with a special territorial status (Scott 1998).

This comparatively low profile of the Viadrina in the cross-border policy landscape was reflected in the reluctance of upper-tier authorities to grant the Euroregion further powers. According to a Brandenburg ministry official, the Euroregion 'has failed to bundle the interests and competencies of the member authorities into a coherent development concept, which has it made completely dependent on funds from Brussels' (iV6). Individuals closer to the Euroregion countered that 'the Land has no trust in the Euroregion, and tends to extract Interreg funds for measures that bear little relation to border issues' (iV3). Despite differences in interpretation, one can conclude that the Viadrina does not enjoy a status comparable to the EUREGIO's position as cross-border agency within its geographic remit.

Finally, the Tyrol Euroregion played only a marginal role in the complex crossborder policy landscape in the Central Alps. Historically, co-operation has long been pursued among the authorities involved. The relationships in the culturaleducational field were particularly well developed - for instance concerning university education. Equally, in the health field, complementarities between the hospitals in South Tyrol and the University clinic in Innsbruck have been exploited in the past. Largely informal co-ordination also occurred on large transport infrastructures, a sensitive issue in the ecologically fragile Alpine area, and other aspects of the environment (iT1). In the wider context of the Eastern Alps, the three regional authorities have also been engaged in the Working Communities Arge Alp and the Alpe-Adria.

For the initiation of these activities preceded the Euroregion, it had no legitimate prerogative to take over the co-ordination of cross-border measures when it was established. Notably, the administration of Interreg was not transferred to the 
Euroregion (as an organisation) but continued to be carried out in conjunction with other EU programmes by the responsible administrative units of the participating authorities. This is despite the fact that many of these projects were criticised even by the policy implementers themselves as they had little genuine cross-border content (iT6). Some Interreg projects were devolved to deconcentrated branches of the regional administrations located in the immediate border areas. These units were historically involved in other EU-funded programmes, such as LEADER, and hence had the required expertise (iT5).

It can be concluded that the impact of the Euroregion as an organisation on the CBC landscape in Tyrol is small. The Euroregion Tyrol is a largely symbolical project promoted by the political leaders of the three regions whereas the practical aspects appear marginal. This Euroregion, therefore, is qualitatively different from the EUREGIO that was constituted through a bottom-up process of regional mobilisation with strongly pragmatic features.

\section{Conclusions}

The use of the concept of policy entrepreneurship as a framework for analysis uncovered considerable variation across the three Euroregions in relation to their organisational set-up and the degree to which they have established themselves as organisations and actors in their own right. The EUREGIO illustrates the 'model' European CBR. It emerged as a result of the successful bottom-up mobilisation of municipalities on the Dutch-German border, led by an entrepreneurial secretariat, and has inserted itself as a legitimate cross-border development agency in its local context across the Dutch-German border.

By contrast, the Viadrina is a latecomer and - in an act of mimetic isomorphism (DiMaggio and Powell, 1983) - adopted a readily available organisational model. For the German local and Land authorities, the purpose of the Euroregion was to have a vehicle to deploy EU Interreg funds in the border area. The effective regional mobilisation - establishing collective action capacity among local actors - was less pronounced than in the EUREGIO, and higher-level authorities, such as the central state and regional authorities, retained stronger control.

The Euroregion Tyrol is an example for a CBR created by a politically driven 
ethno-regional project that has largely failed to develop autonomous organisational capacity. It differs from the EUREGIO and the Viadrina in that it does not involve municipal actors but rather is pursued largely on the basis of a top-level agreement among already established regional authorities. It has remained a confederal envelope as opposed to operating independently as a crossborder agency.

The analysis allows for some careful generalisation on the structural conditions of successful Euroregional policy entrepreneurship, particularly if one considers that Euroregions in similar administrative environments operate in similar ways. The cases suggest that the ability of Euroregions to engage in active policy entrepreneurship is shaped by the politico-administrative environments in which they operate. Two cases were located in Northern Europe whereas one case (Tyrol) is Central-European and involves a Southern European country, Italy. Synthesising the evidence, it appears that the ability of municipalities to engage in collective action - both intra-nationally and then cross-nationally - is important in constituting a strategic opportunity space for Euroregions. In this respect, there are major differences between Northern Europe (Germany, Netherlands, Scandinavia) and countries such as Italy and France. As Page and Goldsmith (1997) argue, Northern European local governments have higher margins of discretion and a broader set of responsibilities supported up by locally raised resources than those in Southern Europe.

This discussion suggests CBRs are more likely to be effective in countries with a strong tradition of municipal autonomy. In the German system, the two-level structure of local authorities - consisting of the municipalities on one hand and district-type aggregations of municipalities (Kreise) on the other - facilitates collective action among municipalities. The (West) German Länder have historically developed a benevolent attitude towards inter-municipal co-operation in general and to CBRs in particular, as this was seen as a way to decentralise the implementation of local regional policies (Voelzkow, 1995).

In this context, the autonomy gained by the Euroregions has allowed them to engage in policy entrepreneurship, exploit windows of opportunities related to the cross-border theme and build organisational competence in cross-border policies 
- as seen in the case of the EUREGIO. Their ability to assert themselves as small, specialised Interreg implementation units - with major implications for their resource base - is one of the foremost examples of this.

Although both are involved in Interreg, differences remain between the EUREGIO, which emerged as a grass roots movement long before Interreg funds were available, and the Viadrina where the availability of Interreg was a major rationale for adopting the form of a Euroregion for creating a CBR. The EUREGIO's more diversified resource base, organisational capacity and legitimacy within the local environment are in stark contrast to the Viadrina whose role is mostly limited to administering Interreg and which has failed to assert itself as a strategic actor in cross-border matters.

The results confirm the broader analyses of 'multi-level governance' policy structures which argue that European regional policies are implemented within complex vertical integration networks exhibiting strong variation across member states. This article has added a micro-perspective on the modalities of agency and strategy formation at the grass roots level; it postulates that policy entrepreneurship and organisation-building are among the main mechanisms for generating durable local action in the multi-level governance framework.

If one agrees that these are desirable characteristics of policy implementation, one can use the conceptual components of policy entrepreneurship to generate a set of success criteria for cross-border regions or similar initiatives. Equally, the framework can inform some of the variables for further, quantitatively oriented research evaluating success or failure of a larger number of Euroregions.

On the broader question as to whether we are witnessing the emergence of a new type of regional territory (cross-border regions), the answer is two-fold: Firstly, the degree to which genuine cross-border agency is established across local crossborder spaces varies strongly, dependent primarily on the territorialadministrative context and specific local conditions for the emergence of such policy entrepreneurship. This comparative case study analysis has shown that in some cases Euroregions represent hardly more than paper tigers while in others one can see the embryonic emergence of cross-border regional governance structures linked to a cross-border agency. 
Secondly, even in those cases where cross-border agency has been successfully institutionalised, it appears premature to attribute the characteristics of a 'region' to these entities. Although they assume pseudo-territorial features, and engage in strategies of cross-border identity building invoking territorial imaginaries, their relative dimensions in terms of organisational size and resource control are still small compared to the established public authorities on either side of the border (Perkmann, 2007). Rather, they constitute an institutional form through which existing authorities engage in collective action across nation-state borders. We need to regard Euroregions as part of the dynamic policy innovation scenario induced by EU integration rather than as new territorial entities strictly speaking.

Acknowledgements: Thanks to Bob Jessop, Andrew Sayer, André Spicer and the referees for their input at various stages, and Adrienne Cole for her competent help. An earlier version was presented at the workshop on 'Strategies for Collaborative Regional Development across the Korea-Japan Strait', Busan (South Korea), 24-26 June 2004; thanks to Won Bae Kim. Research funded by the European Commission via individual Marie Curie Fellowship FMBICT961862.

\section{References}

Anderson J, O'Dowd, L, Wilson, T H, 2003 New borders for a changing Europe: cross-border cooperation and governance (Frank Cass: London)

Anderson M, 1997 “Transfrontier co-operation - history and theory”, in Grenzüberschreitende Zusammenarbeit in Europa: Theorie - Empirie Praxis, Eds G Brunn, P Schmitt-Egner (Nomos, Baden-Baden) pp 78-97

Balme R, Ed, 1996 Les politiques du néo-régionalisme. Action collective régionale et globalisation (Economica, Paris)

Beck J, 1997 Netzwerke in der transnationalen Regionalpolitik: Rahmenbedingungen, Funktionsweise, Folgen (Nomos: Baden-Baden)

Benz A, Eberlein B, 1999, “The Europeanization of regional policies: patterns of multi-level governance" Journal of European Public Policy 6 329-48 
Blatter J K, 2001 "Debordering the world of states: Towards a multi-level system in Europe and a multi-polity system in North America insights from border regions" European Journal of International Relations 7 175-209

Brenner N, 1999 "Globalisation as reterritorialisation: The re-scaling of urban governance in the European union" Urban Studies 36(3): 431-451

Brouard S, 1996 "L'Arc Atlantique comme entreprise politique: coopération interrégionale et leadership politique" in Les politiques du néo-régionalisme, Ed R Balme (Economica: Paris)

Brunet-Jailly E, 2004 “Comparing Local Cross-Border Relations under the EU and NAFTA" Canadian-American Public Policy 58

Carmin J, Hicks B, Beckmann A, 2003. "Leveraging local action - Grassroots initiatives and transboundary collaboration in the formation of the White Carpathian Euroregion” International Sociology 18 703-725

Church A, Reid P, 1999 “Cross-border co-operation, institutionalization and political space across the English Channel” Regional Studies 33 643-655

Cochrane A, Peck J, Tickell A, 1996 "Manchester plays games: exploring the local politics of globalisation" Urban Studies 33 1319-1336

CoE, 1972 1. Europäisches Symposium der Grenzregionen. Die Zusammenarbeit europäischer Grenzgebiete (Council of Europe, Strassbourg)

Cohen M D, March J G, Olsen J P, 1972, “A garbage-can model of organizational choice” Administrative Science Quarterly 17 1-25

Conzelmann T, 1998. ""Europeanisation" of regional development policies? Linking the multi-level governance approach with theories of policy learning and policy change." European Integration online Papers 2(4): http://eiop.or.at/eiop/texte/1998-004a.htm

Dicken P, 1998 Global shift. (Chapman, London)

DiMaggio P J, Powell W W, 1983 "The iron cage revisited: institutional isomorphism and collective rationality in organizational fields" American Sociological Review 48 147-160

Eisenhardt K M, 1989 "Building theories from case study research" Academy of Management Review 14 532-550.

Gabbe J, 1985 “EUREGIO: regionale grenzüberschreitende Zusammenarbeit auf 
kommunaler Ebene" in Staatsgrenzen überschreitende Zusammenarbeit des Landes Nordrhein-Westfalen, Ed Institut für Landes- und Stadtentwicklungsforschung (ILS, Dortmund) pp. 90-98

Grix J, Knowles V, 2003 “The Euroregion and maximisation of social capital: Pro Europa Viadrina" in New borders for a changing Europe: cross-border cooperation and governance Eds J Anderson, L O'Dowd, M W Thomas (Cass, London) pp. 154-176

Heinelt H, R. Smith R, Eds, 1996. Policy networks and European Structural Funds (Avebury: Aldershot)

Heinelt H 1996, "Perspektiven und Probleme der Strukturfondsförderung" in Politiknetzwerke und europäische Strukturfondsförderung Ed H Heinelt (Leske + Budrich, Opladen) pp 298-308

Hooghe L, Marks G, 2003 “Unraveling the Central State, but How? Types of Multi-level Governance" American Political Science Review 97(2) 233243.

Hooghe L Ed, 1996 Cohesion policy and European integration: building multilevel governance (Oxford University Press: Oxford)

Jessop B, 2002 "The political economy of scale" Globalization, regionalization and cross-border regions, Eds. M Perkmann, N-L Sum (Palgrave, Houndsmills) pp 25-49

Jessop B, 2004 "The European Union and recent transformations in statehood" in The state of Europe: transformations of statehood from a European perspective Eds S P Riekmann, M Mokre, M Latzer (Campus, Frankfurt) pp 75-94.

Kaplan D, Häkli J, Eds, 2002 Boundaries and Place: European borderlands in geographical context (Rowman \& Littlefield, Lanham)

King P J, Roberts N C, 1987 "Policy entrepreneurs - catalysts for policy innovation" Journal of state government 60 172-178.

Kingdon J W, 1984. Agendas, alternatives, and public policies (Little Brown, Boston)

Laffan B, 1997 "From policy entrepreneur to policy manager: the challenge facing the European Commission” Journal of European Public Policy 4(3) 
$422-38$

Liberda E, 1996 Regionalentwicklung in Grenzregionen: Eine Euregio als Regionalentwicklungsstrategie? (Passavia, Passau)

Luverà B, 1996 Oltre il confine. Regionalismo europeo e nuovi nazionalismi in Trentino-Alto Adige (il mulino, Bologna)

Majone G, Tame C, 1996 Regulating Europe (Routledge, London)

March J G, Olsen J P, 1984 “The New Institutionalism: Organizational Factors in Political Life" The American Political Science Review 78(3) 734-749

Marks G, 1996 "Exploring and explaining variation in EU cohesion policy" in Cohesion policy and European integration: building multi-level governance Ed L Hooghe (Oxford University Press, Oxford) pp 388-422

McCarthy J D, Zald M N, 1977 "Resource Mobilization and Social Movements" American Journal of Sociology 82 1212-1241

Mintrom M, Vergari S, 1996 “Advocacy coalitions, policy entrepreneurs, and policy change" Policy Studies Journal 24:420-434

Mintrom M, 1997 Policy Entrepreneurs and the Diffusion of Innovation. American Journal of Political Science 41(3) 738-770

Moravcsik A, 1999 "New Statecraft? Supranational Entrepreneurs and International Cooperation” International Organization 53(3) 267-306

Olson M, 1965 The logic of collective action (Harvard University Press: Cambridge MA)

Perkmann M, 2002 "Euroregions. Institutional entrepreneurship in the European Union" in Globalization, regionalization and cross-border regions Eds M Perkmann, N-G. Sum (Palgrave, Houndsmills) pp 103-124

Perkmann M, 2003 “Cross-border regions in Europe. Significance and drivers of cross-border co-operation" European Urban and Regional Studies 10 (2) $153-71$

Perkmann M, 2007 "Construction of new scales. A framework and case study of the EUREGIO cross-border region” Regional Studies 41(2): 253-266

Roberts N C, King P J, 1996 Transforming public policy: dynamics of policy entrepreneurship and innovation (Jossey-Bass, San Francisco)

Scott J W, 1998 "Planning cooperation and transboundary regionalism: 
implementing policies for European border regions in the German-Polish context" Environment and planning C 16 605-624

Scott J W, 1999 "European and North American contexts for cross-border regionalism” Regional Studies 33(7) 605-618

Sidaway J D, 2001 "Rebuilding bridges: a critical geopolitics of Iberian transfrontier cooperation in a European context" Environment and Planning D 19(6) 743-778

Smyrl M E, 1997 "Does European community regional policy empower the regions?" Governance 10:287-309.

Speiser B, 1993 Europa am Oberrhein (Helbing Lichtenhahn: Basel)

Sum N-L, 2002 "Rearticulation of spatial scales and temporal horizons of a crossborder mode of growth: the (re)making of Greater China" in Globalization, regionalization and cross-border regions Eds M Perkmann, N-L Sum (Palgrave, Houndsmills) pp 151-175

Tömmel I, 1994 Staatliche Regulierung und europäische Integration: Die Regionalpolitik der EG und ihre Implementation in Italien (Nomos, Baden-Baden)

Toniatti R, 1997 “La bozza di statuto della Regione europea” in Europaregion Tirol. Rechtliche Voraussetzungen und Schranken der Institutionalisierung, Eds P Pernthaler and S Ortino (Autonome Region Trentino-Südtirol, Bozen) pp. 17-38

Turnock D, 2002 "Cross-border cooperation: A major element in regional policy in East Central Europe" Scottish Geographical Journal 118:19-40

Voelzkow H, 1995 “Die Regionalisierung der Strukturpolitik und neue Formen einer intermediären Interessensvermittlung" in Steuerungseffekte und Legitimation regionaler Netzwerke Ed H. Kilper (Institut Arbeit und Technik, Gelsenkirchen), pp. 7-40

\section{Annex: Interview codes}

iB1 European Commission, DG16, INTERREG II/c (spatial planning), Brussels (BE) 
iB2 European Commission, DG16, INTERREG II, Brussels

iB3 European Commission, DG12, Brussels

iB4 European Commission, DG16, Internal inter-regional co-operation, Brussels iB5 European Commission, DG16, innovative actions, Brussels

iB6 LACE-TAP office, Brussels

iB7 European Commission, DG1, Brussels

iB8 European Commission, DG16, Brussels

iE1 Overijssel Province, Zwolle (NL)

iE2 Landkreis Grafschaft Bentheim, Nordhorn (DE)

iE3 Ministry of Economic Affairs (Dutch government), Regio Oost, Arnhem $(\mathrm{NL})$

iE4 Bezirkregierung Weser-Ems, Oldenburg (DE)

iE5 EUREGIO, Gronau (DE) (group interview).

iE6 Bezirkregierung, Abteilung Regionalplanung und Wirtschaft, Münster (DE)

iE7 Beleidsmedewerker Economische Zaken en Grensoverschrijdende Samenwerking, Regio Acherhoek (NL)

iE8 EUREGIO, Gronau (DE)

iE9 Landkreis Steinfurt, Steinfurt (DE)

iE10 NRW.Bank, Düsseldorf (DE)

iE11 Ministry of Economics, SMEs, Technology and Transport, Land NordrheinWestfalen, Düsseldorf (DE) 
iE12 Kreis Borken, Stabstelle, Bocholt (DE)

iE13 EUREGIO secretariat (DE)

iT1 Provincia Autonoma di Bolzano-Alto Adige, Bolzano (IT)

iT2 University of Innsbruck, Innsbruck (AT)

iT3 Consiglio Provinciale, Provincia Autonoma di Bolzano-Alto Adige, Bolzano (IT)

iT4 Department for European affairs, Provincia Autonoma di Bolzano-Alto Adige, Bolzano (IT)

iT5 LEADER co-ordination unit, Schluderns (IT)

iT6 Department for European affairs, Provincia Autonoma di Bolzano-Alto Adige, Bolzano (IT)

iT7 Regione Autonoma Friuli-Venezia Giulia, Udine (IT)

iT8 Interreg unit, Land Tirol, Innsbruck (AT)

iV1 IRS/Institute for Regional Development and Structural Planning, Erkner (DE)

iV2 European Universiy Viadrina, Frankfurt/Oder (DE)

iV3 European Universiy Viadrina, Frankfurt/Oder (DE)

iV4 Institute of Urban Development and Dwelling (ISW), Frankfurt/Oder (DE)

iV5 Euroregion secretariat, Frankfurt/Oder (DE)

iV6 Ministry of Justice and Federal and European Affairs, Land Brandenburg, Potsdam (DE)

iV7 Viadrina University, Frankfurt/Oder (DE)

iV8 Regionale Planungsgemeinschaft Oderland-Spree, Beeskow (DE) 
iV9 City of Frankfurt/Oder (DE)

iV10 Gemeinsame Landesplanungsabteilung Berlin/Brandenburg, Frankfurt/Oder (DE)

iV11 Investors' Center, Technology Park, Frankfurt/Oder (DE)

iV 12 Ministry of Economics, SMEs and Technology, Land Brandenburg, Potsdam (DE)

iV13 Euroregion secretariat (DE)

iV14 City of Gorzów (PL) 


\section{Tables and figures}

Table 1: General characteristics of the cases

\begin{tabular}{|l|l|l|l|}
\hline & EUREGIO (DE/NL) & Viadrina (DE/PL) & $\begin{array}{l}\text { Tyrol Euroregion } \\
\text { (AT/IT) }\end{array}$ \\
\hline $\begin{array}{l}\text { Specific border } \\
\text { regime }\end{array}$ & $\begin{array}{l}\text { Open border } \\
\text { scenario (ex D-Mark } \\
\text { block) }\end{array}$ & $\begin{array}{l}\text { Former external EU } \\
\text { border (persisting } \\
\text { border) }\end{array}$ & $\begin{array}{l}\text { Recently open } \\
\text { (Austria's EU } \\
\text { accession) }\end{array}$ \\
\hline $\begin{array}{l}\text { Historical } \\
\text { background }\end{array}$ & $\begin{array}{l}\text { Post-war } \\
\text { reconciliation }\end{array}$ & $\begin{array}{l}\text { Alienation in } \\
\text { socialist period }\end{array}$ & Common ethnicity \\
\hline $\begin{array}{l}\text { Inter-State } \\
\text { relationships }\end{array}$ & $\begin{array}{l}\text { Early bi-national } \\
\text { treaty on cross- } \\
\text { border co-operation, } \\
\text { 'CBC-friendly', }\end{array}$ & $\begin{array}{l}\text { Neighbourhood } \\
\text { agreement, } \\
\text { rapprochement } \\
\text { between Germany } \\
\text { and Poland }\end{array}$ & $\begin{array}{l}\text { Politically sensitive } \\
\text { minority issue, 1995 } \\
\text { treaty on cross- } \\
\text { border co-operation }\end{array}$ \\
\hline $\begin{array}{l}\text { Dominant level } \\
\text { of co-operation }\end{array}$ & $\begin{array}{l}\text { Municipalities } \\
\text { Municipalities, } \\
\text { ltrong role of higher } \\
\text { level authorities }\end{array}$ & Regional authorities \\
\hline Policy problem & $\begin{array}{l}\text { Manage inter- } \\
\text { dependencies and } \\
\text { promote cross-border } \\
\text { functional } \\
\text { integration }\end{array}$ & $\begin{array}{l}\text { Attract investment, } \\
\text { stimulate economic } \\
\text { growth, cultural } \\
\text { relationships }\end{array}$ & $\begin{array}{l}\text { Symbolic territorial } \\
\text { politics }\end{array}$ \\
\hline $\begin{array}{l}\text { Strategic context } \\
\text { of cross-border } \\
\text { agency }\end{array}$ & $\begin{array}{l}\text { Long established } \\
\text { inter-municipal co- } \\
\text { operation with clear } \\
\text { CBR focus }\end{array}$ & $\begin{array}{l}\text { Only recent } \\
\text { development of } \\
\text { intermunicipal co- } \\
\text { operation (partly } \\
\text { externally imposed) }\end{array}$ & $\begin{array}{l}\text { Weak sense of } \\
\text { cross-border agency }\end{array}$ \\
\hline
\end{tabular}

Table 2: Criteria for policy entrepreneurship

\begin{tabular}{|l|l|l|l|}
\hline & EUREGIO & Viadrina & Tyrol Euroregion \\
\hline $\begin{array}{l}\text { CBR } \\
\text { organisation }\end{array}$ & $\begin{array}{l}\text { Secretariat (high } \\
\text { degree of autonomy) }\end{array}$ & $\begin{array}{l}\text { Secretariat (low degree } \\
\text { of autonomy) }\end{array}$ & $\begin{array}{l}\text { Range of agencies } \\
\text { associated with } \\
\text { regional authorities } \\
\text { (fragmented) }\end{array}$ \\
\hline Resource base & Diversified & Dependent on Interreg & Not developed \\
\hline $\begin{array}{l}\text { CBC } \\
\text { appropriation }\end{array}$ & High & Low & Low \\
\hline
\end{tabular}

